\author{
KRZYSZTOF PAPUGA ${ }^{1}$, JAROSŁAW KASZUBKIEWICZ ${ }^{1 *}$, WITOLD WILCZEWSKI ${ }^{2}$, \\ MICHAŁ STAŚ ${ }^{2}$, JERZY BELOWSKI ${ }^{2}$, DOROTA KAWAŁKO ${ }^{1}$ \\ ${ }^{1}$ Wroctaw University of Environmental and Life Sciences, Institute of Soil Science and Environmental Protection \\ Grunwaldzka 53, 50-357 Wroctaw, Poland \\ 2 Arcanum Sp. z o.o., Parkowa 6/1, 51-616 Wroctaw, Poland
}

\title{
Soil grain size analysis by the dynamometer method - a comparison to the pipette and hydrometer method
}

\begin{abstract}
The aim of the presented work was to compare the results of grain size distribution measurement by an innovative dynamometer method, developed by the authors, with results obtained by the pipette and hydrometer methods. Repeatability of results obtained in the dynamometer method was also determined. The content of three fractions with equivalent diameters $<0.002 \mathrm{~mm}$, $0.002-0.063 \mathrm{~mm}$ and $0.063-2.0 \mathrm{~mm}$ was measured. The results were compared using ordinary linear regression and additionally in the repeatability analysis by RMA (reduced major axis regression). It was found that the proposed dynamometer method is characterized by good result repeatability with no systematic errors when compared with the pipette method. The RMSE (root mean square error) value when referring to the pipette method calculated for the three fractions considered in total was 4.9096 and was lower than the analogous for the hydrometer method, which amounted to 5.4577. Values of determination coefficients in the comparison of dynamometer method and pipette method are within the range of $0.9681-0.9951$ for the different fractions. It was found that slightly larger differences in relation to the pipette method occurred for the fractions $<0.002 \mathrm{~mm}$ and $0.002-0.063 \mathrm{~mm}$, and smaller for the fraction $0.063-2.0 \mathrm{~mm}$. Similarly, greater differences between repetitions in the dynamometer method were observed for the fraction $<0.002 \mathrm{~mm}$, and smaller for the $0.063-2.0 \mathrm{~mm}$ fraction. Possible sources of errors in the dynamometer method were discussed, as were proposals for their reduction.
\end{abstract}

Keywords: grain size composition, dynamometer method, pipette method, settling velocity

\section{INTRODUCTION}

Soil grain size composition is the basic property used to predict other physical features (Trzecki 1974, 1976; Gimenez et al. 2001, Walczak et al. 2006, Lamorski et al. 2014, Brogowski and Kwasowski 2015). It is most often determined by sieve-sedimentation methods. These methods have been developed for several dozen years (Bouyoucos 1927, Köhn 1928, Casagrande 1934) and now allow achieving results with satisfactory repeatability and validity (Rząsa and Owczarzak 2013). In terms of dimensions below $0.1 \mathrm{~mm}$, they use differences in settling velocities of soil particles, with different equivalent diameters (Gee and Bauder 1986).

Diversified grain settling velocity results in measurable changes in the density of the suspension both in terms of time and distance from the suspension surface. Measurements of the suspension density are currently performed in a variety of ways: suspension is taken up and evaporated (Indorante et al. 1990, Gee and Or 2002), measured with a hydrometer (Komornicki and Jakubiec 1978, Ryżak et al. 2009), measurement of X-ray absorption (Buchan et al. 1993) and even measuring the pressure of the suspension at a given depth (Zhang and Tumay 1995, Kovács et al. 2004, Durner et al. 2017).

Sedimentation analysis is supplemented with sieve analysis due to the settling velocity of grains with diameters greater than $0.1 \mathrm{~mm}$ preventing sample absorption or measuring its density by means of a hydrometer in a given time. Therefore, two separate physical phenomena (sedimentation and sieving under dry and wet conditions) are used to determine the soil grain size distribution. The set of fractions determined by the sieve method is defined by the number and size of meshes used in the screens.

Recently, a new method has been proposed (Kaszubkiewicz et al. 2017) for determining the suspension density and hence the soil grain size distribution. The method is based on the measurement of the apparent weight of a float immersed in the suspension over time. The apparent weight measurement is performed using a sensitive piezoelectric dynamometer.

The change of a float's position in the suspension during the measurement is in fractions of a millimeter. Measurements of the suspension density with a float can therefore be performed at a strictly selected depth 
with a frequency of up to $0.1 \mathrm{~s}$. In this article, this will be called the dynamometer method.

The use of new measurement method obviously raises the problem of comparability of results with that obtained so far, the quantity of accidental and systematic errors and test result repeatability. The first tests of the method showed its satisfactory compliance with the results obtained in the pipette method and correctness of results for artificially prepared soil mixtures (Kaszubkiewicz et al. 2017).

The aim of this study is to evaluate the conformity of the results of the dynamometer method with the hydrometer and pipette method for broader experimental material covering the soils of different textural groups.

\section{MATERIALS AND METHODS}

Samples representing 59 genetic horizons of soils of varied structure and genesis have been selected for the research and measurement evaluation. In total, in terms of grain size distribution (measured using the hydrometer method), these samples belonged to the following granulometric groups according to PTG (PTG 2008): sands-16, sands, loamy sands-4, sandy loams-5, loams-5, clay loams-5, silty clay loam- 1 , silt loams- 12 , clays- 7 , heavy clays- 4 . The samples were characterized by median values of diameters $\left(d_{50}\right)$ ranging from $<0.002 \mathrm{~mm}$ to $0.245 \mathrm{~mm}$. The average median value calculated for samples for which the value of $d_{50}$ ( 45 samples) could be read was $0.099 \mathrm{~mm}$ and the standard deviation was 0.081 . For 14 samples the value of $d_{50}$ was below $0.002 \mathrm{~mm}$, which made it impossible to calculate (the extrapolation method was omitted as unreliable).

The samples contained less than $1 \%$ of $\mathrm{CaCO}_{3}$ (as determined by Scheibler's method) and less than 1\% of organic carbon content (as determined by wet oxidation method).

In all samples, the grain size distribution was determined by Casagrande's hydrometer method modified by Prószyński (according to PN- ISO 11277 , 2005) by pipette method in accordance with Köhn (Gee and Bauder 1986) and by the dynamometer method. In the case of pipette and hydrometer method, the methodology described in the work of Ryżak et al. (2009) has been applied. The dynamometer method is described in Kaszubkiewicz et al. (2017). It consists in determining the density changes of the suspension at a depth $z$ in time $t$ by measuring the apparent weight of the float immersed in it.

Taking change in density into consideration, the content of individual soil fractions can be calculated using the Stokes equation (1850). In relation to the method described in the above cited work, the following modifications were used: the shape of the float was changed and at the same time its volume was increased to $41.48 \mathrm{~cm}^{3}$ and weight (in the air) to $49.26 \mathrm{G}$, a thin metal low stretch wire was used instead of a monofilament to hang the float and continuous temperature measurement was introduced. Changes were also made to the software, taking into account the time elapsing from the end of mixing to pressing the automatic measuring switch, and calculation of the mean of several results for short measurement times was improved.

The dynamometer measurements were made again for 23 samples at an interval of 24 hours to determine repeatability. In the dynamometer method the content of fraction $<0.002,0.002-0.004,0.004-0.006,0.006-$ $0.008,0.008-0.016,0.016-0.02,0.02-0.032,0.032-$ $0.05,0.05-0.063,0.063-0.1 \mathrm{~mm}$ was determined. The content of fraction $0.1-0.25,0.25-0.5,0.5-1.0$ and $1.0-2.0 \mathrm{~mm}$ was determined entirely by sieve method. Content of fractions $<0.002,0.002-0.063$, and $0.063-$ $2.0 \mathrm{~mm}$ used for comparisons of the three methods were calculated by appropriate summation.

With the hydrometer method the standard set of fractions $<0.002,0.002-0.006,0.006-0.02,0.02-$ $0.05,0.05-0.1 \mathrm{~mm}$ was determined. The content of fractions $0.1-0.25,0.25-0.5,0.5-1.0$ and $1.0-2.0 \mathrm{~mm}$ was determined by sieving.

The fraction of particles with equivalent diameters below $0.063 \mathrm{~mm}$ was calculated by interpolation using a particle distribution model, which was a renormalized lognormal function (Buchan 1989, Buchan et al. 1993, Esmaeelnejad et al. 2016). Subsequently, the content of fraction $<0.002,0.002-0.063$, and $0.063-2.0 \mathrm{~mm}$ was determined by appropriate summation.

With the use of pipette method, the content of fractions $<0.002,0.002-0.063$, and $0.063-2.0 \mathrm{~mm}$ was measured.

\section{RESULTS AND DISCUSSION}

\section{Compliance with the pipette method}

The pipette method is considered the reference when determining grain size distribution. It is essentially used to validate other methods (Syvitski 1991, Allen 1997, Orzechowski et al. 2014). The results obtained are characterized by high repeatability. It uses a simple and understandable mathematical model of the phenomenon of sedimentation (Stokes 1850, Dietrich 1982). Its main shortcomings are, of course, considerable labour and time consumption. It was also treated as a reference method in the presented work. 

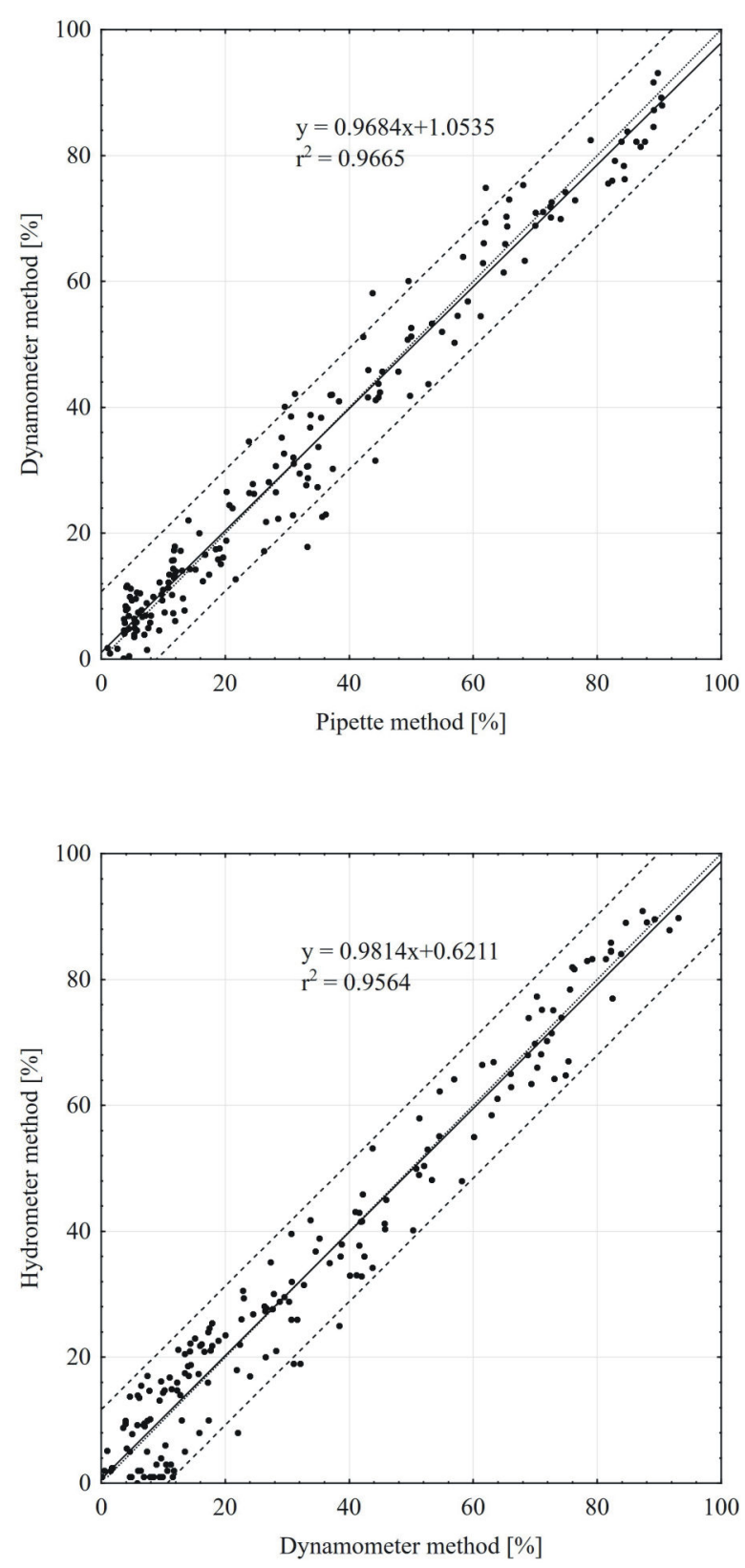

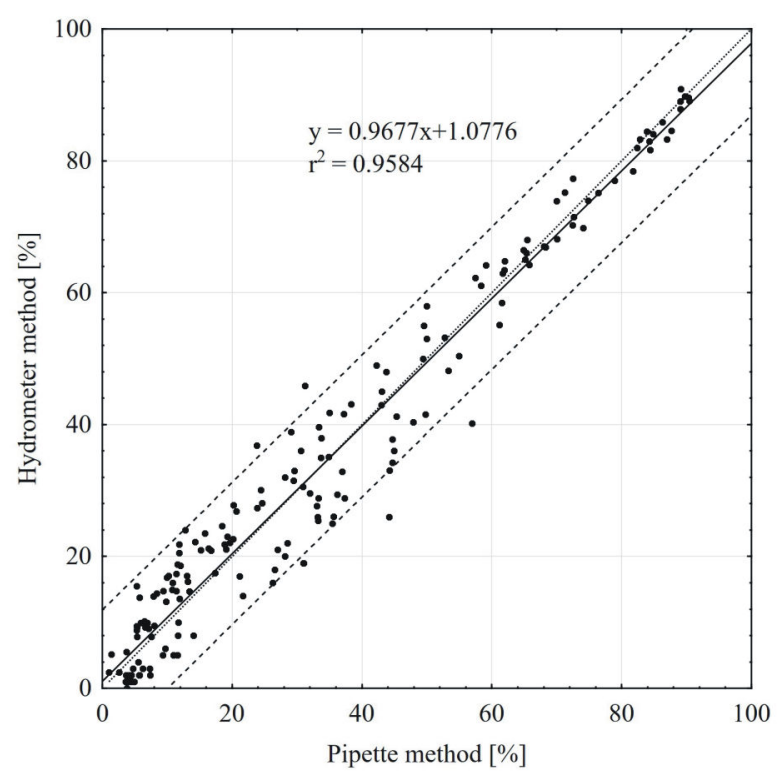

FIGURE 1. Relationships between the content of fractions $<0.002$, $0.002-0.063$, and $0.063-2.0 \mathrm{~mm}$ determined by dynamometer, hydrometer and pipette methods (the dashed line represents the $5 \%$ significance level for the mean value)

TABLE 1. Comparison of results obtained using the dynamometer and pipette method

\begin{tabular}{lclllllc}
\hline Fraction $\mathrm{mm}$ & $\begin{array}{l}\text { No. of } \\
\text { samples }\end{array}$ & $\begin{array}{l}\text { Regression } \\
\text { equation }\end{array}$ & $\begin{array}{l}\text { Correlation } \\
\text { coefficient }\end{array}$ & $\begin{array}{l}\text { Std. error of } \\
\text { slope } \\
\text { coefficient }\end{array}$ & $\begin{array}{l}\text { Root mean } \\
\text { square error }\end{array}$ & $\begin{array}{l}\text { Std. error of } \\
\text { regression }\end{array}$ & $\begin{array}{l}\text { Critical } \\
\text { value* }\end{array}$ \\
\hline $0.063-2.0$ & 59 & $\mathrm{y}=0.9625 \mathrm{x}+0.2739$ & 0.9951 & 0.0127 & 3.7275 & 3.2931 & -0.2846 \\
\hline $0.002-0.063$ & 59 & $\mathrm{y}=0.9992 \mathrm{x}-0.5335$ & 0.9681 & 0.0343 & 5.4107 & 5.4750 & 0.5340 \\
\hline$<0.002$ & 59 & $\mathrm{y}=1.0217 \mathrm{x}-1.4148$ & 0.9699 & 0.0340 & 5.3985 & 5.1183 & -1.3848 \\
\hline All fractions & 177 & $\mathrm{y}=0.9684 \mathrm{x}-1.0535$ & 0.9831 & 0.0136 & 4.9096 & 4.8634 & -1.0879 \\
\hline
\end{tabular}

$* \mathrm{x}$ value (fraction content measured in the pipette method) for which $\mathrm{y}=0$

The content of fraction $<0.002,0.002-0.063$, and $0.063-2.0 \mathrm{~mm}$ were determined directly using the pipette method. The determinations were made for 59 samples obtaining a total of 177 measurements. Suspensions for dynamometer and pipette measurements were prepared separately. The results of the comparison for the pipette and dynamometer methods are presented in Figure 1and 2. Selected statistical parameters are summarized in Table 1. 

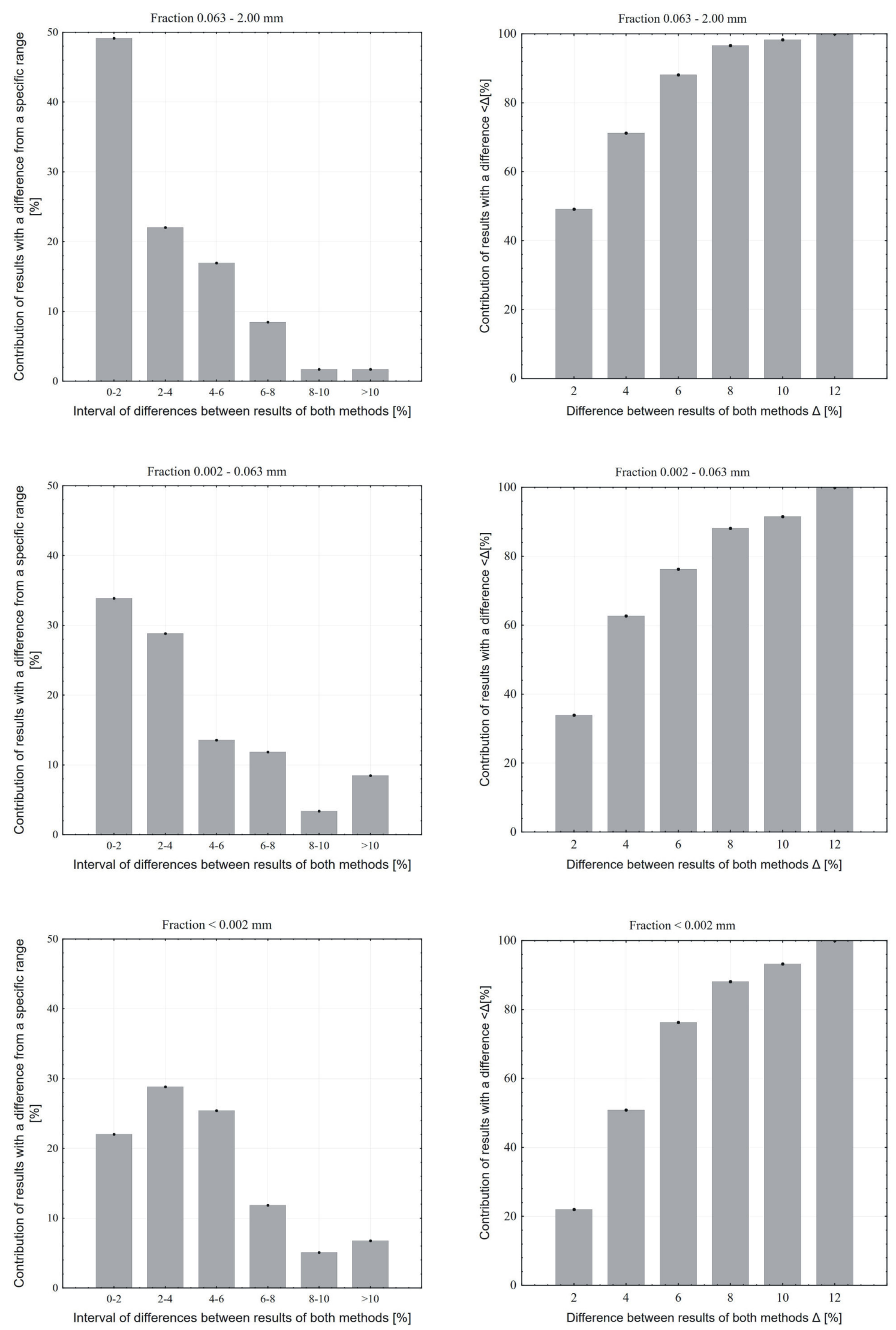

FIGURE 2. Distribution functions and histograms of differences (absolute values) between the results obtained with the use of pipette and dynamometer method for the three tested fractions 
TABLE 2. Comparison of results obtained using the hydrometer and pipette method

\begin{tabular}{lcllllll}
\hline Fraction $\mathrm{mm}$ & $\begin{array}{l}\text { No. of } \\
\text { samples }\end{array}$ & $\begin{array}{l}\text { Regression } \\
\text { equation }\end{array}$ & $\begin{array}{l}\text { Correlation } \\
\text { coefficient }\end{array}$ & $\begin{array}{l}\text { Std. error of } \\
\text { slope } \\
\text { coefficient }\end{array}$ & $\begin{array}{l}\text { Root mean } \\
\text { square error }\end{array}$ & $\begin{array}{l}\text { Std. error } \\
\text { of regression }\end{array}$ & $\begin{array}{l}\text { Critical } \\
\text { value* }\end{array}$ \\
\hline $0.063-2.0$ & 59 & $\mathrm{y}=0.9204 \mathrm{x}+5.4505$ & 0.9957 & 0.0113 & 4.4060 & 2.9203 & -5.9222 \\
\hline $0.002-0.063$ & 59 & $\mathrm{y}=0.8959 \mathrm{x}+4.2248$ & 0.9588 & 0.0352 & 5.9668 & 5.6116 & -4.7159 \\
\hline$<0.002$ & 59 & $\mathrm{y}=1.0483 \mathrm{x}-3.8113$ & 0.9704 & 0.0345 & 5.8603 & 5.2002 & 3.6355 \\
\hline All fractions & 177 & $\mathrm{y}=0.9685 \mathrm{x}+1.0489$ & 0.9791 & 0.0152 & 5.4577 & 5.4228 & -1.0829 \\
\hline
\end{tabular}

$* x$ value (fraction content measured in the pipette method) for which $y=0$

Trend lines for the relationship between the results of both methods only slightly deviated from the line $y=x$. The trend line equation for all fractions together is $y=0.9684 \mathrm{x}-1.0535$, and the correlation coefficient is 0.9831 . The results for individual 3 fractions look similar when analysed separately. Trend line slope coefficients for the all fractions are within the range of 0.9625-1.0217 and are significant at $p<10^{-6}$. The root mean square error was the highest for the $0.002-0.063$ fraction and was 5.4107 , and the lowest for the $0.063-2.0 \mathrm{~mm}$ fraction was 3.7275 . For $25 \%$ of measurements, the absolute difference between the results obtained by both methods (all fractions evaluated together) was less than $1.36 \%$ and for $50 \%$ of the results did not exceed $3.03 \%$, and for $75 \%$ of measurements it was less than $5.29 \%$. Differences greater than $10.50 \%$ were found in $5 \%$ of measurements.

The observed scheme of results indicates the lack of major systematic errors in the dynamometer method and the occurrence of some random errors that require elimination or at least a reduction in the course of further development.

For the hydrometer method evaluated in the analogous system, with the acceptance of the results of the pipette method as the reference, the following results were obtained. The trend line equation for all fractions together is $y=0.9685 \mathrm{x}-1.0489$, and the correlation coefficient is 0.9791 (Table 2, Fig. 1). The slope coefficients for the three analysed fractions are more diverse than for the dynamometer method. They are within the range of $0.8959-1.0483$ and are significant at the level of $p<10^{-6}$. The root mean square error was the highest for the $0.002-0.063$ fraction and was 5.9668 , and the lowest for the $0.063-2.0 \mathrm{~mm}$ fraction was 4.4060 .

The course of the trend line and critical values indicate systematic underestimation of fraction $<0.002$ in all samples by about $3-4 \%$ in relation to the pipette method and overestimation of fraction $0.002-0.063 \mathrm{~mm}$ in sandy soils and also overestimation of fraction $0.063-2.0 \mathrm{~mm}$ in all tested samples (Table 2, Fig. 2).
For $25 \%$ of measurements, the absolute difference between the results obtained by both methods (all fractions evaluated together) was less than $1.64 \%$, for $50 \%$ of the results it did not exceed $3.41 \%$, and for $75 \%$ of the measurements it was less than $6.02 \%$. In $5 \%$ of measurements, differences greater than $10.28 \%$ were detected.

Both dynamometer and hydrometer methods showed compliance with the results of the pipette method at a similar level, with the correlation coefficients differing slightly as did the mean square errors. The presented dynamometer method does not show systematic deviations, and errors are accidental. On the other hand, instead of random errors, the hydrometer method has also a systematic error, which, in relation to the pipette method, underestimates the fraction of the clay at the same time overestimating the content of sandy fractions. Warzyński et al. (2018) arrived at similar conclusions.

\section{Repeatability of results obtained with the dynamometer method}

The repeatability of results obtained in the dynamometer method was evaluated for the same fractions as described above. The repeat measurement was carried out 24 hours after the previous one, in the same suspension after possible supplementation of small water losses associated with evaporation. Measurements of individual fractions were made at the same depths and after the same times. Possible small differences in the experimental conditions could be related to temperature changes in the laboratory.

In a system of this kind, random factors such as ground vibrations transmitted to the device, changes in temperature during the measurement, instability of the electronic components of the measurement system (drift error) and other factors difficult to determine may have influenced the results. The only systematic factor that could affect the results would be the possible breakdown of aggregates or even grains during the period between the first and the second measurement. 
The tests were repeated for 23 samples and in total 69 fractions were analysed. The results are presented in Figure 3. The statistical parameters are summarized in Table 3. As can be seen, the trend lines for the relationship between measurements for $0.002-0.063$, $0.063-2.0 \mathrm{~mm}$ fractions and for all the fractions together practically do not differ from the $y=x$.
The only trend line for the comparison of two measurements of fraction contents $<0.002 \mathrm{~mm}$ clearly deviates from the line $y=x$. The slope coefficients of the trend line are significant at the level of $p<10^{-6}$. The value of the correlation coefficient for the total of 3 fractions is 0.9947 . For $25 \%$ of the results, the difference between the first and the second measurement
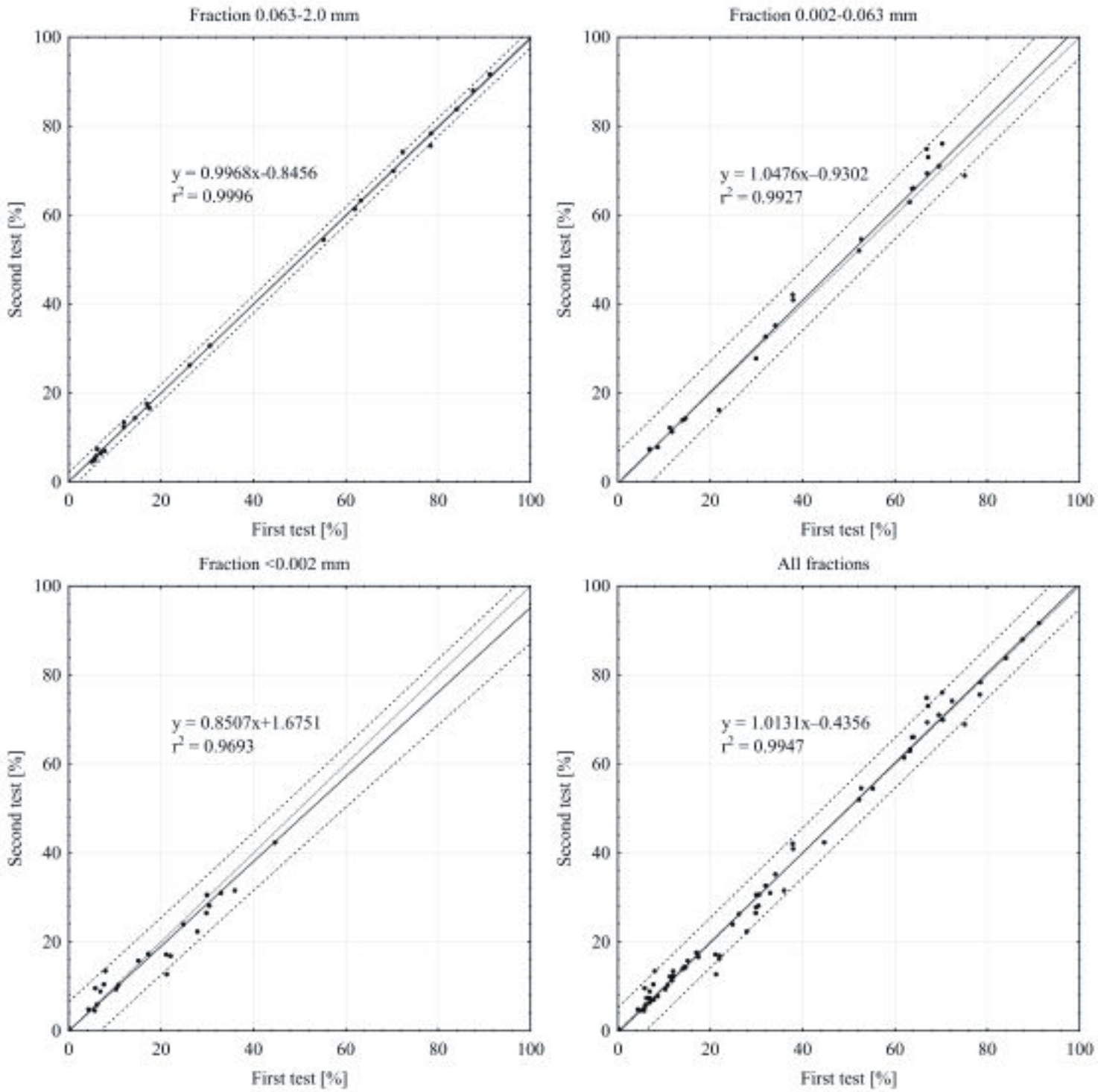

FIGURE 3. Comparison of results obtained in repeated measurements, for these same soils, with the use of dynamometer method

TABLE 3. Comparison of repetitions in the dynamometer method

\begin{tabular}{lllllllc}
\hline Fraction $\mathrm{mm}$ & $\begin{array}{l}\text { No. of } \\
\text { samples }\end{array}$ & $\begin{array}{l}\text { Regression } \\
\text { equation }\end{array}$ & $\begin{array}{l}\text { Correlation } \\
\text { coefficient }\end{array}$ & $\begin{array}{l}\text { Std. error of } \\
\text { slope } \\
\text { coefficient }\end{array}$ & $\begin{array}{l}\text { Root mean } \\
\text { square error }\end{array}$ & $\begin{array}{l}\text { Std. error } \\
\text { of regression }\end{array}$ & $\begin{array}{l}\text { Critical } \\
\text { value* }\end{array}$ \\
\hline $0.063-2.0$ & 23 & $\mathrm{y}=0.9968 \mathrm{x}-0.8456$ & 0.9996 & 0.0061 & 0.9043 & 0.9395 & -0.0848 \\
\hline $0.002-0.063$ & 23 & $\mathrm{y}=1.0476 \mathrm{x}-0.9302$ & 0.9927 & 0.0279 & 3.3731 & 3.1323 & 0.8879 \\
\hline$<0.002$ & 23 & $\mathrm{y}=0.8507 \mathrm{x}+1.6751$ & 0.9693 & 0.0471 & 3.3019 & 2.6956 & -1.9691 \\
\hline All fractions & 69 & $\mathrm{y}=1.0131 \mathrm{x}-0.4356$ & 0.9947 & 0.0128 & 2.7747 & 2.7944 & 0.4299 \\
\hline
\end{tabular}

* $\mathrm{x}$ value (fraction content measured in the pipette method) for which $\mathrm{y}=0$ 
was less than $0.43 \%$, for $50 \%$ of the results it was less than $0.84 \%$ and for $75 \%$ it was lower than $2.40 \%$. In $5 \%$ of measurements, differences greater than $5.88 \%$ were found.

Analysis of repeated cumulative particle size distribution function (PSD-not included in the paper) it was revealed that the differences between measurements are twofold. In the first case, a single point on the PSD curve in one of the repetitions clearly stands out from the second repetition and additionally from the trend for the whole curve. In the second, we deal with a more systematic deviation of the course of both curves at a certain distance.

Achieving even better repeatability of measurements by eliminating random errors would most probably be possible after improving the insulation of the system from ground vibration and by stabilizing the laboratory room temperature.

The ordinary regression analysis used above is based on the assumption that an independent variable (fraction content measured with pipette method) is measured without error. The dependent variable is loaded with a measurement error.

In the case when both variables $x$ and $y$ are loaded with measurement errors, it is suggested the Reduced Main Axis Analysis is used instead of the usual regression (Smith 2009, Harper 2014). The simple regression in RMAA is determined in this way, so that the sum of the rectangular triangle fields between the measuring points and the straight one is the smallest. Using this regression model, the equations listed in Table 4 were obtained. As can be seen an analysis of results using both methods give almost the same parameters of regression equation.

\section{The influence of some factors on the results of measurements}

Under real conditions during sedimentation process, each particle experiences a different fluid resistance due to variable arrangements of adjacent particles, emerging local pressure gradients, eddies caused by larger, rapidly drooping grains, water countercurrents and wall effects (Ham and Homsy 1988, Syvitsky 1991, Nguyen and Laad 2005).

Variable fluid resistance due to the presence of other particles and the water movement caused by them means that settling velocity of grains depends on suspension concentration and composition. The actual settling velocity $w$ is therefore different from the one calculated from the Stokes equation, and the difference increases with the suspension concentration. The literature contains many equations describing the relationship between $w_{0}$ and $w$ considering the concentration of suspension and the size and shape of settling particles (van Rijn 1989, Cheng 1997, Ahrens 2000). The most commonly used equation binding both speeds is the empirical Richardson-Zaki formula (Richardson and Zaki, 1954):

$$
\omega=\omega_{0}(1-c)^{m}
$$

where $c$ is the volume concentration of the suspension, and $m$ is the parameter determined experimentally. The Richardson-Zaki formula is used for suspensions with a volume concentration of $0.05<_{c}<0.5$. For suspensions with $c<0.05$ Batchelor (1982), (Batchelor and Wen 1982) introduced a modified formula:

$$
\omega=\omega_{0}(1-n c)
$$

where the value of parameter $n$ is from 5.5 to 6.5 (Silva et al. 2015).

Therefore, it can be expected that the results obtained in sedimentation methods, where the volumetric suspension concentrations used are at the level of $0.01-0.03$ will depend on the applied sample determining the concentration of the suspension and thus the actual grain settling velocity.

The deviation from the Stokes equation will be greater in heavy soils due to the higher concentration of fractions remaining in the suspension for a long time. For example, for soil containing $50 \%$ of clay fraction at a weight of solid phase in the suspension equal to $60 \mathrm{~g}$ and the parameter value $n=5.5$, the ratio $\omega / \omega_{\mathrm{o}}$ is 0.94 .

The phenomenon is very complicated in nature because grain settling velocity depends on the grain concentration in suspension, and this on the grain size distribution, which is yet to be measured. The obvious solution of the problem would be to reduce the sample's weight and concentration, but this would require measuring the density changes that are smaller than now. This would increase the significance of random errors.

There was an attempt at an initial assessment of this phenomenon in terms of its impact on the results obtained in the proposed measurement method. The content of selected fractions $(f<0.05$ and $f<0.015$ $\mathrm{mm}$ ) was measured by means of the dynamometer method at several depths after times calculated with the Stokes' equation.

As can be seen in Figure 4 and as shown in the paper of Kaszubkiewicz et al. (2017), results of measurements of the same fraction in the dynamometer method may vary by $2-4 \%$ depending on the measurement depth, and depending on the sample weight varies by 1 to $6 \%$. Larger differences could be observed for larger depths of measurements. 
As results from the Richardson-Zaki formula, the interaction of grains cause that its settling velocity is lower than calculated from the Stokes' formula. Therefore, the adopted measurement times are too short and, in the moment of measurement, in the suspension there are still grains with equivalent diameters larger than the assumed ones.

It can be expected that the difference between the assumed and the actual diameters will be greater for the fractions with larger equivalent diameters because they are measured in a suspension with a higher concentration, and therefore with larger deviations of the actual and calculated settling velocity.

A possible solution to the problem may be a reduction of the weight of soil sample and its differentiation due to initial organoleptic assessment. As a result, more homogeneous sedimentation conditions for different samples can be achieved.

The description of phenomena causing some differentiation of results for the same fraction obtained at different depths requires further theoretical and
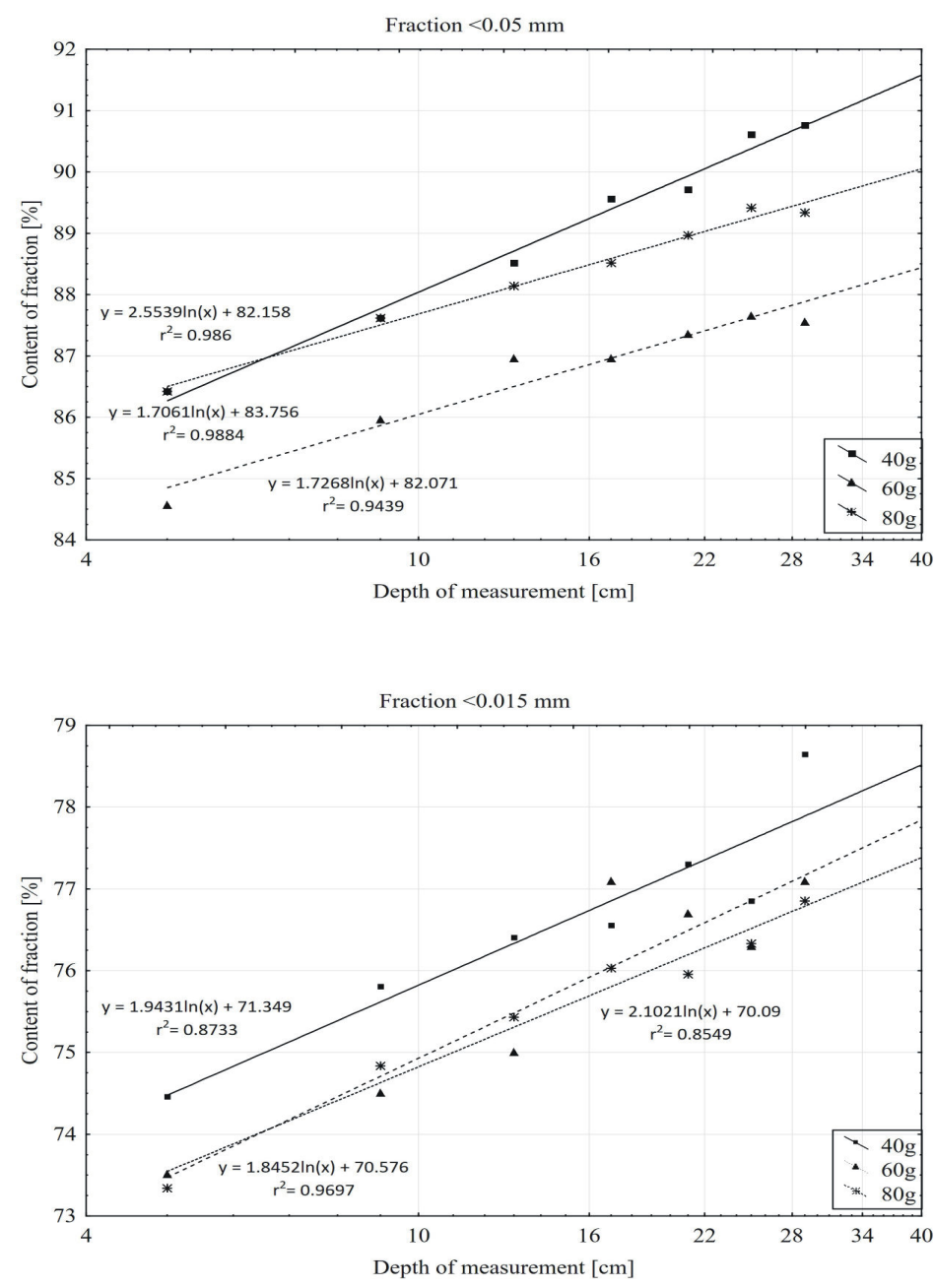

FIGURE 4. Comparison of results obtained for these same fractions, for different samples weights and at different depths (single selected sample) experimental research, TABLE 4. Comparison of repetiwhich the authors plan tions in the dynamometer method to carry out in the near future. with the use of RMA analysis

Theexact approach $0.063-2.0 \quad \mathrm{y}=0.997 \mathrm{x}+0.069$ to determine time of $0.002-0.063 \quad \mathrm{y}=1.055-1.258$ particle settling would $<0.002 \quad \mathrm{y}=0.878 \mathrm{x}+1.185$ also require determi- All fractions $\quad \mathrm{y}=1.022 \mathrm{x}-0.008$ nation of specific density of soil solid phase. It can be assumed that at low contents of organic matter, its impact on density is small (Blake and Hartge 1986). The impact of differentiated mineral density and hence the different density of fractions included in a single soil (Mocek et al. 2009) is not included in any of the available methods.

However, one should not expect effects related to the particle's motion phase until reaching the final settling velocity when they accelerate after shaking the suspension (Allen 1997). According to Gee et al. (2002) the time required for a particle with a diameter of $5 \mathrm{~mm}$ to reach $99 \%$ of the final settling velocity is $0.017 \mathrm{~ms}$, and for a particle of $1000 \mu \mathrm{m}-1000 \mathrm{~ms}$.

The deviation of particle shape from spherical has a significant influence on the settling velocity. In the literature on the subject, many empirical equations can be found to calculate the settling velocity of real soil grains (Gibbs et al. 1971, Ahrens 2000, Jimenez and Madsen 2003).

Various indexes describing the shape of grains are used such as the Coreya index (Jimenez and Madsen 2003) or the Janke index (Janke 1966). Any deviation from the spherical shape results in a decrease of the settling velocity in relation to the spherical grain of the same volume as the tested ones. On the other hand, the surface smoothness turns out to be less important (Baba and Komar 1981).

A simple solution to this problem seems to be the use of an equivalent diameter concept as the diameter of the sphere falling at a speed equal to the real shape grain. However, this is a solution that has a significant role in the emerging discrepancies between the sedimentation and optical methods (Polakowski et al. 2014).

The above comments apply equally to all three sedimentation methods, and the differences between the methods result mainly from the use of different sample weights and different measurement depths. 


\section{SUMMARY}

From a wide range of methods of grain size analysis none can be considered ideal (Goossens 2008), and their evaluation depends on the criteria used.

The method for determination of grain size distribution in the range of $0.002-0.1 \mathrm{~mm}$ diameters proposed by Kaszubkiewicz et al. (2017) gives a satisfactory compatibility of results with the results of the pipette method considered as a reference as well as the hydrometer method. There is no need to enter the calibration of dynamometer method to achieve the convergence of results with the pipette method.

The observed differences in results in relation to the reference method are accidental in nature, but no systematic differences were observed. Systematic differences were observed for the hydrometer method, which, in relation to the reference, underestimates the clay fraction content and overestimates the content of fraction $0.002-0.063 \mathrm{~mm}$ for sandy soils.

The dynamometer method shows good reproducibility of the results, with a slightly higher dispersion for the clay fraction and for the silt fraction (0.002$0.063 \mathrm{~mm}$ ).

Subsequent improvements of the method both in terms of its physical aspects and the use of improved computational algorithms should lead to further improvement of compliance with reference and repeatability of results.

In order to reduce the effects of interaction between sedimenting particles on the results of the analysis, it is reasonable to standardize the concentration of suspensions for soils with different fine fraction contents. For this purpose, the team is going to introduce variation of sample weight depending on the organoleptic evaluation of soil texture.

Summarizing the main advantages of the developed method, these are, in addition to the consistency of the results with the reference method, a direct record of the results in digital form, the capacity to analyse multiple fractions with arbitrarily chosen ranges of diameters and the reduction of the analysis time in relation to other sedimentation methods.

\section{ACKNOWLEDGMENTS}

The research was carried out with the financial support from the Intelligent Development Operational Program, contract No. POIR.02.03.02-02-0008/16-01, project title: Significant improvement of the innovative device for measuring the grain size composition of fine-grained materials.

\section{REFERENCES}

Ahrens J.P., 2000. The fall-velocity equation. Journal of Waterway, Port, Coastal, and Ocean Engineering 126(2): 99-102.

Allen T., 1997. Particle size measurement. Vol. 1., Chapman and Hall, London, UK.

Baba J., Komar P.D., 1981. Settling velocity of irregular grains at low Reynolds numbers. Journal of Sedimentary Petrology 51(1): 121-128.

Batchelor G.K., 1982. Sedimentation in a Dilute Polydisperse System of Interacting Spheres. Part 1. General Theory. Journal of Fluid Mechanics 119: 379-408.

Batchelor G.K., Wen C.S., 1982. Sedimentation in a Dilute Polydisperse System of Interacting Spheres. Part 2. Numerical Results. Journal of Fluid Mechanics 124: 495- 582.

Blake G.R., Hartge K.H., 1986. Bulk density. [In:] Methods of Soil Analysis, Part 1- Physical and Mineralogical Methods, 2nd Edition, Agronomy Monograph 9 (Klute A., Editor). Soil Science Society of America, Madison: 363-382.

Bouyoucos G.J., 1927. The hydrometer as a new method for the mechanical composition of soils. Soil Science 23: 343-354.

Brogowski Z., Kwasowski W., 2015. An attempt of using soil grain size in calculating the capacity of water unavailable to plants. Soil Science Annual 66(1): 21-28.

Buchan G.D., Grewal K.S., Robson A.B., 1993a. Improved models of particle-size distribution: an illustration of model comparison techniques. Soil Science Society of America Journal 57: 901-908.

Buchan G.D., Grewal K.S., Claydon J.J., McPherson R.J., 1993b. A comparison of Sedigraph and pipette methods for soil particle-size analysis. Australian Journal of Soil Research 31(4): 407-417.

Buchan G.D., 1989. Applicability of the simple lognormal model to particle-size distribution in soils. Soil Science 147: 155-161.

Casagrande A., 1934. Die Aräometer Methode zur Bestimmung der Kornverteilung von Böden, Springer, Berlin: 56 pp.

Cheng N.S., 1997. A simplified settling velocity formula for sediment particle. Journal of Hydraulic Engineering 123(2): 149-152.

Dietrich W., 1982. Settling velocity of natural particles. Water Resources Research 18(6): 1615-1626.

Durner W., Iden S.C., Unold G., 2017. The integral suspension pressure method (ISP) for precise particle-size analysis by gravitational sedimentation. Water Resources Research 53: 33-48.

Esmaeelnejad L., Siavashi F., Seyedmohammadi J., Shabanpour M., 2016. The best mathematical models describing particle size distribution of soils. Modelling Earth Systems and Environment 2: 166 .

Gee G.W., Or D., 2002. Particle-size analysis. [In:] Methods of Soil Analysis. Part 4. Physical and Mineralogical Methods. 4th Edition (Dane J.H. and Topp G.C., Editors). Soil Science Society of America, Madison: 255-293.

Gee G.W., Bauder J.W., 1986. Particle-size analysis. [In:] Methods of Soil Analysis: Part 1. Physical and Mineralogical Methods, 2nd edition (Klute A., Editor). Soil Science Society of America, Madison: 383-411.

Gibbs R.J., Matthews M.D., Link D.A., 1971. The relationship between sphere size and settling velocity. Journal of Sedimentary Research 41(1): 7-18. 
Gimenez D., Rawls W.J., Pachepsky Y., Watt J.P.C., 2001. Prediction of a pore distribution factor from soil textural and mechanical parameters. Soil Science 166: 79-88.

Goossens D., 2008. Techniques to measure grain-size distributions of loamy sediments: a comparative study of ten instruments for wet analysis. Sedimentology 55(1): 65-96.

Ham J.M., Homsy G.M., 1988. Hindered settling and hydrodynamic dispersion in quiescent sedimenting suspensions. International Journal of Multiphase Flow 14: 533-546

Harper W.V., 2014. Reduced major axis regression: teaching alternatives to least squares. 9th International Conference on Teaching Statistics, Contributed Paper.

Indorante S.J., Follmer L.R., Hammer R.D., Koenig P.G., 1990. Particle-size analysis by a modified pipette procedure. Soil Science Society of America Journal 54(2): 560-563.

Janke N.C., 1966. Effect of shape upon the settling velocity of regular convex geometric particles. Journal of Sedimentary Research 36(2): 370-376.

Jimenez J.A., Madsen O.S., 2003. A Simple Formula to Estimate Settling Velocity of Natural Sediments. Journal of Waterway, Port, Coastal, and Ocean Engineering 129(2): 70-78.

Kaszubkiewicz J., Wilczewski W., Nowak T.J., Woźniczka P., Faliński K., Belowski J., Kawałko D., 2017. Determination of soil grain size composition by measuring apparent weight of float submerged in suspension. International Agrophysics 31(1): 61-72.

Köhn M., 1928. Beitrage zur Theorie und Praxis der mechanischen Bodenanalyse. Landwirtschaft Jahrbuch 67: 485-546.

Komornicki T., Jakubiec J., 1978. Remarks on the areometric method for soil mechanical analysis as modified by M. Prószyński. Part 5: A comparison of several granulometric methods. Acta Agraria et Silvestria. Series Agraria 1: 83-95.

Kovács B., Czinkota I., Tolner L., Czinkota G., 2004. The determination of particle size distribution (PSD) of clayey and silty formations using the hydrostatic method. Acta mineralogicapetrographica 45: 29-34.

Lamorski K., Bieganowski A., Ryżak M., Sochan A., Sławiński C., Stelmach W., 2014. Assessment of the usefulness of particle size distribution measured by laser diffraction for soil water retention modelling. Journal of Plant Nutrition and Soil Science 177(5): 803-813.

Mocek A., Owczarzak W., Tabaczyński R., 2009. Uziarnienie oraz skład mineralogiczny frakcji ilastej czarnych ziem Gniewskich. Roczniki Gleboznawcze - Soil Science Annual 60(3): 123-132.

Nguyen N-Q., Ladd A.J.C., 2005. Sedimentation of hard-sphere suspensions at low Reynolds number. Journal of Fluid Mechanics 525: 73-104.

Orzechowski M., Smólczyński S., Długosz J., Poźniak P., 2014. Measurements of texture of soils formed from glaciolimnic sediments by areometric method, pipette method and laser diffraction method. Soil Science Annual 65(2): 72-79.

Particle size distribution and textural classes of soils and mineral materials - classification of Polish Society of Soil Sciences 2008. Roczniki Gleboznawcze - Soil Science Annual 60(2): 5-16.
PN-ISO 11277:2005 Jakość gleby- Oznaczanie składu granulometrycznego w mineralnym materiale glebowym - Metoda sitowa i sedymentacyjna.

Polakowski C., Sochan A., Bieganowski A., Ryżak M., Földényi R., Tóth J., 2014. Influence of the sand particle shape on particle size distribution measured by laser diffraction method. International Agrophysics 28: 195-200.

Richardson J.F., Zaki W.N., 1954. Sedimentation and fluidisation. Part 1. Transactions of the Institution of Chemical Engineers, 32: $35-53$.

Ryżak M., Bartmiński P., Bieganowski A., 2009. Metody wyznaczania rozkładu granulometrycznego gleb mineralnych. Acta Agrophysica 175: 84 pp.

Rząsa S., Owczarzak W., 2013. Methods for the granulometric analysis of soil for science and practice. Polish Journal of Soil Science 46(1): 1-50.

Silva R., Garcia F., Faia P., Rasteiro M., 2015. Settling Suspension Flow Modeling: A review. KONA Powder and Particle Journal 32: 41-56.

Smith R.J., 2009. Use and misuse of the reduced major axis for line-fitting. American Journal of Physical Anthropology 140(3): 476-86.

Stokes G.G., 1850. On the effect of the internal friction of fluids on the motion of pendulums. Transactions of the Cambridge Philosophical Society 9: 8-106.

Syvitski J.P.M., 1991. Principles methods and application of particle size analysis. Cambridge University Press, Cambridge: 388 pp.

Trzecki S., 1976. Possibility of determination of the moisture of permanent wilting of plants on the basis of maximal higroscopicity and content of clayey particles in mineral soils. Roczniki Gleboznawcze - Soil Science Annual 27(4): 11- 18.

Trzecki S., 1974. Determination of water capacity of soils on the basis of their mechanical composition. Roczniki Gleboznawcze - Soil Science Annual 25(suppl.): 33-44.

Walczak R.T., Moreno F., Sławiński C., Fernandez E., Arrue J.L., 2006. Modeling of soil water retention curve using soil solid phase parameters. Journal of Hydrology 329(3-4): 527-533.

Warzyński H., Sosnowska A., Harasimiuk A., 2018. Wpływ zróżnicowanej zawartości materii organicznej i węglanów na wyniki oznaczania składu granulometrycznego metodą areometryczną Casagrande'a w modyfikacji Prószyńskiego. Soil Science Annuals (in Press).

van Rijn L.C., 1989. Handbook: Sediment transport by currents and waves. Report H461, Delft Hydraulics, Netherlands: 480 pp.

Zhang Z., Tumay M.T., 1995. Granulometric evaluation of particle size using suspension pressure during sedimentation. Geotechnical Testing Journal 18(1): 121-129.

Received: February 8, 2018

Accepted: May 28, 2018

Associated Editor: J. Rejman 


\section{Analiza skladu granulometrycznego gleby metodą dynamometryczną - porównanie $z$ metodą pipetową $\mathbf{i}$ areometryczną}

Streszczenie: Celem przedstawianej pracy było porównanie wyników składu granulometrycznego zmierzonego za pomocą innowacyjnej metody dynamometrycznej, opracowanej przez autorów, z wynikami uzyskanymi w metodzie areometrycznej i traktowanej jako referencyjna, metodzie pipetowej. Określono również powtarzalność wyników uzyskiwanych w metodzie dynamometrycznej. Mierzono zawartość trzech frakcji o wymiarach $<0,002 \mathrm{~mm}, 0,002-0,063 \mathrm{~mm}$ i $0,063-2,0 \mathrm{~mm}$. Wyniki porównywano z zastosowaniem regresji liniowej, a przy analizie powtarzalności dodatkowo za pomocą analizy RMA (reduced major axis). Stwierdzono, że proponowana metoda dynamometryczna charakteryzuje się dobrą powtarzalnością wyników i brakiem błędów systematycznych przy porównaniu z metodą pipetowa. Wartość RMSE (root mean square error) przy odniesieniu do metody pipetowej obliczona dla 3 frakcji rozpatrywanych łącznie wynosiła 4,9096 i była mniejsza od analogicznej obliczonej dla metody areometrycznej, dla której wyniosła 5,4577. Wartości współczynników determinacji przy porównaniu metod dynamometrycznej i pipetowej mieszczą się, dla różnych frakcji, w granicach 0,9681-0,9951. Stwierdzono, że nieco większe różnice wyników w relacji do metody pipetowej występują przy pomiarze frakcji $<0,002 \mathrm{~mm}$ i $0,002-0,063 \mathrm{~mm}$, a mniejsze dla frakcji $0,063-2,0 \mathrm{~mm}$. Podobnie większe różnice pomiędzy powtórzeniami w metodzie dynamometrycznej zaobserwowano dla frakcji $<0,002 \mathrm{~mm}$, a mniejsze dla frakcji $0,063-2,0 \mathrm{~mm}$. Przedyskutowano możliwe źródła błędów w metodzie dynamometrycznej i określono ewentualne sposoby ich redukcji.

Słowa kluczowe: skład granulometryczny, metoda dynamometryczna, metoda pipetowa, prędkość opadania ziaren 